\title{
EXPOSITION IN STONE FOREST NATIONAL PARK: INTERNATIONAL COOPERATION BETWEEN SLOVENIA AND CHINA IN RESEARCH AND DEVELOPMENT OF STONE FOREST UNESCO GLOBAL GEOPARK
}

Informal cooperation between Slovenian and Chinese karstologists started as early as 1980 's, but the main boost was initiated after 1995 in the frame of several national and international projects. Fruitful long-term cooperation between the Karst Research Institute, Research Centre of

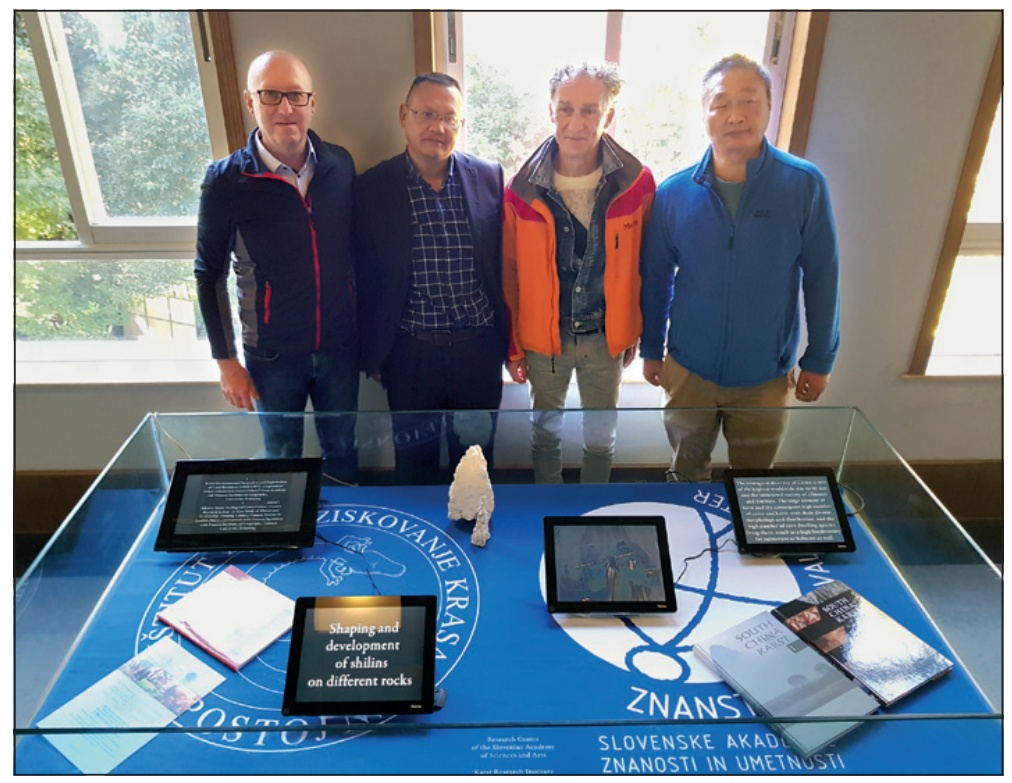

Opening of the permanent exhibition dedicated to Slovenian-Chinese cooperation on karst research in Stone Forest Karst Museum, 17 November 2018. From the left: Martin Knez (Karst Research Institute, Research Centre of the Slovenian Academy of Sciences and Arts), Huang Jin (Stone Forest Karst Geological Research Center), Tadej Slabe (Karst Research Institute, Research Centre of the Slovenian Academy of Sciences and Arts), and Liu Hong (International Joint Research Center for Karstology, Yunnan University). the Slovenian Academy of Sciences and Arts, and Yunnan Institute of Geography, Yunnan University, successfully culminated in many joint research efforts, among which the research in Stone Forest (Shilin) in South China Karst was the most apparent one.

The Yunnan University International Joint Research Center for Karstology was established in 2012 with the support of the leadership of the Yunnan province, and within the Center, Yunnan International Karst Environmental Laboratory started to operate. To upgrade a successful long-term cooperation, agreement between the Stone Forest Research Centre of Stone Forest Scenic Spot Administration, Yunnan University International Joint Research Center for Karstology and Karst Research Institute, Research Centre of the Slovenian Academy of Sciences and Arts, to strengthen international karstonacle karst and cone karst formations. These features reflect the evolution and development of this particular landscape which holds multi-stage and diverse karst forms. Complex geological evolution of this karst terrain, which included submerge period of ancient sea, tectonic activities and weathering, is clearly observed in the rocks since late Palaeozoic, although the main strata belong to Devonian, Carboniferous and Permian carbonate rocks.

Tourist visitation of the area, which has been protected since the 1930's, has risen significantly after 1978, when the territory was officially open for tourism. Close cooperation between Slovenian and Chinese researchers supported to unravel some mechanisms in the evolution of these natural phenomenon. The results assisted the successful candidature of Shilin's designation as UNESCO World Heritage Site in 2007. Nowadays, ap- 
proximately four million tourists visit the site, and the wider surrounding area additional six million more. The proper presentation of such natural phenomenon is vital for tourists, particularly for those who want to understand profoundly the formation of stone forest, its evolution and projection in the future along with the diversity of biota, and ethnological and cultural elements of Sani and Yi people.

Inside the Shilin protected area, there is Stone Forest Karst Geological Museum that holds a great collection of different geological and biological items which are presented in a highly attractive manner. Inside the park, there is also another museum, the Stone Forest Karst Museum with a smaller collection, but more focused on the local history of stone forest formation, and is intended for smaller groups. A part of the story on stone forest evolution was assisted by the researchers of the Karst Research Institute, Research Centre of the Slovenian Academy of Sciences and Arts, from Postojna, and this is now on a display. This new interactive presentation in the museum shows the history of Slovenian-Chinese scientific cooperation in karst research between 1995 and 2018, joint explorations on the field, and the results of geological and hydrological investigation in the area with the biodiversity in caves (Figure).

Janez Mulec Tadej Slabe Martin Knez Liu Hong 